\title{
Making the Gold Coast a Smart City-An Analysis
}

\author{
Isara Khanjanasthiti *(0), Kayalvizhi Sundarraj Chandrasekar and Bhishna Bajracharya \\ Faculty of Society \& Design, Bond University, Gold Coast 4226, Australia; kayal@bond.edu.au (K.S.C.); \\ bbajrach@bond.edu.au (B.B.) \\ * Correspondence: ikhanjan@bond.edu.au
}

Citation: Khanjanasthiti, I.; Chandrasekar, K.S.; Bajracharya, B. Making the Gold Coast a Smart City-An Analysis. Sustainability 2021, 13, 624. https://doi.org/ $10.3390 /$ su131910624

Academic Editor: Tan Yigitcanlar

Received: 18 August 2021

Accepted: 18 September 2021

Published: 24 September 2021

Publisher's Note: MDPI stays neutral with regard to jurisdictional claims in published maps and institutional affiliations.

\begin{abstract}
In recent times, there has been a worldwide trend towards creating smart cities with a focus on the knowledge economy and on information and communication technologies. These technologies have potential applications in managing the built and natural environments more efficiently, promoting economic development, and actively engaging the public, thus helping build more sustainable cities. Whilst the interest in smart cities has been widespread predominantly amongst metropolitan cities, several regional cities such as the Gold Coast in Australia have also recently endeavoured to become smart cities. In response to this emerging trend, this study aimed to investigate key opportunities and challenges associated with developing regional cities into smart cities using the Gold Coast as a case study. It identified key factors critical to the planning and development of smart cities. These factors fall under five broad themes: cultural and natural amenities, technology, knowledge and innovation precincts, people and skills, and governance. The factors were applied to the Gold Coast to analyse the key opportunities and challenges for its development into a smart city. Finally, key lessons, which are potentially applicable to other regional cities seeking to develop into smart cities, are drawn from the case study.
\end{abstract}

Keywords: smart cities; regional cities; technology; governance; knowledge workers; knowledge precincts; open data; Gold Coast

\section{Introduction}

Many cities worldwide are now facing several ongoing challenges, such as increasing traffic volume and congestion, diminishing quality of life, urban sprawl, and a degrading natural environment. To address these challenges, several cities are now seeking to establish themselves as smart cities. Several metropolitan cities such as London, Barcelona [1], Seoul, Hong Kong, Tokyo, and Singapore [2] have been at the forefront of these trends [3]. Recently, however, a growing number of regional cities in Australia, such as the Gold Coast, the Sunshine Coast, Launceston, and Gawler, have also shown interest in establishing themselves as smart cities. This trend became highly evident following the $\$ 50$ million Smart Cities and Suburbs program by the Australian Federal Government launched in 2016 [4], which is delivered through City Deals, another Federal initiative. Throughout the two application rounds to date, several local government agencies of non-metropolitan cities have successfully secured funding support for their smart city projects, thus illustrating the growing level of interest in smart cities amongst regional cities in Australia.

The Gold Coast is Australia's sixth most populated and largest non-capital regional city and yet is often regarded as an "overgrown resort town" [5]. The city has traditionally been "Australia's playground" [6] with its beautiful surf beaches, rainforests, and theme parks that attract domestic travellers and, lately, an increasing number of international tourists [7]. Contrary to its early days, the cultural and creative identities of the Gold Coast have continued to evolve, especially since hosting the 2018 Commonwealth Games [8]. The 2016-2017 budget plan of the City of Gold Coast (CoGC), the local government agency responsible for managing the Gold Coast, has specifically allocated \$3.6 million to Digital City, a smart city project. The project seeks to identify, investigate, and provide emerging 
opportunities, including smart lighting, smart travel, and smart health initiatives [9]. Since then, a few projects have been underway or in the pipeline under the Digital City platform.

Given this context, this study aimed to explore major opportunities and challenges that regional cities encounter in their endeavour to become smart cities. It identified key factors for the successful development of smart cities and analysed a case study of the Gold Coast using these factors. This article comprises two sections. The first section is a literature review of smart city concepts, which provides a basis for an analytical framework of smart cities. The second section applies the framework to the Gold Coast to identify key opportunities and challenges the city is facing in its development into a smart city. The case study analysis is based on a review of relevant policy documents and web-based resources related to the Gold Coast. Lastly, the article concludes with key lessons from the case study, which are potentially applicable to other regional cities seeking to establish themselves as smart cities.

\section{Literature Review}

The literature on smart cities has grown exponentially in the last decade, e.g., [10-13]. However, despite the growing body of knowledge, no universally accepted definition currently exists for smart cities [14-18]. Several terms such as "smart," "smarter," "digital," "intelligent," "knowledge-based," and "ubiquitous" are used interchangeably in the smart city literature [10,19].

\subsection{What Are Smart Cities?}

According to Townsend [13] (p. 15), smart cities are "places where information technology is combined with infrastructure, architecture, everyday objects, and even our bodies to address social, economic, and environmental problems." He also proposes that these cities have the prospect of being efficient, transparent, resilient, secure, and sociable. Smart cities rely upon an appropriate mix of human capital (e.g., skilled labour), infrastructure capital (e.g., telecommunication infrastructure), social capital [20], and entrepreneurial capital [21]. Recently, Alizadeh [22] (p. 71) has defined smart cities as "urban settlements that capitalise on telecommunication technologies to enhance liveability, workability and sustainability." This definition highlights the importance of telecommunication infrastructure in creating smart cities. Several information and communication technologies (ICTs) (e.g., smartphones, radio frequency identification, sensors, and drones) have enabled crowdsourcing of data from the public to be conducted efficiently without compromising privacy and security [12,22]. There is an opportunity for open data to be harnessed for addressing the long-term challenges that cities are facing [23]. Such data can be used by different stakeholders to provide a variety of useful information products and services for local communities.

Although smart cities are structurally "wired" and supported by an integrated system of ICTs, the use of technologies alone does not automatically make cities "smart." Hollands [14] (p. 315) stated that "smart cities must seriously start with people and the human capital." Therefore, ensuring "the balance between using advanced technology and still maintaining the humanness aspect" is an essential consideration for smart cities [24] (p. 30). Traditionally, smart cities primarily focused on corporate marketing needs on an incremental and piecemeal basis $[25,26]$. However, contemporary smart cities should invest in intellectual capital by accumulating a funding policy strategy that promotes social, cultural, and environmental development [3,27], which is often disregarded in smart city frameworks [28]. This process can also help cities achieve socio-economic equality, a critical element of smart cities, by engaging all citizens in a problem-solving process to build a socially inclusive society [29-31].

In addition to technology and people, institutions form another key component of smart cities, and there is a need for governance to encourage public participation and build institutional capacity [32,33]. Paskaleva [34] highlighted the importance of using 
knowledge networks and e-governance to boost a city's competitiveness. Strategic plans to promote e-governance and integration of ICTs are also vital for developing smart cities [35].

\subsection{Critique of Smart Cities}

According to Yigitcanlar [36], although the smart city movement has a prospect, the topic is still under exploration and, therefore, not well-developed. Thus, the smart city concept is not an effective urban development and management model in its current stage. Moreover, "local characteristics, priorities and the needs" of the city often influence the smart city landscape [36] (p. 32). Several cities around the world have implemented strategies to become smarter over the last decade. Nevertheless, in doing so, the simplistic use of such terms as "smart" and "intelligent" has emerged primarily for marketing purposes, resulting in the failure to specify which aspects of their intelligence are being enhanced and how they intend to achieve a high level of intelligence [37-39]. Cities seeking to establish themselves as smart cities can also appear elitist [18,40]. Many cities, through their desire to join the "smart city elite," are adding several embellishments to the "smart" definition of smart cities beyond the technology dimension, thus making the smart city concept more convoluted [41] (p. 2).

According to Saunders and Baeck [42], smart city ideas have often been criticised in three ways. Firstly, they have been overly focused on hardware and hard infrastructure rather than people, even though cities should be for people [43]. Secondly, given the rapid advancement in technologies in recent years, there has been an overemphasis on finding uses for new technologies rather than finding appropriate technologies to solve major urban problems. Thirdly, similarly to Komninos' [39] argument above, several smart cities have concentrated on marketing and promoting themselves at the expense of testing different solutions in the real world.

In his review of current smart city practices, Yigitcanlar [29] discovered that cities worldwide are trialling different technologies to improve their operation. Cities are employing technologies to achieve smart city objectives in vastly different ways, even in the same country. This trend illustrates that a one-size-fits-all approach is not appropriate for implementing smart city initiatives due to each city's unique characteristics, context, and issues [24]. A one-size-fits-all narrative, which does not adequately consider socioeconomic, spatial, and political variables in the local context, has been identified as one of the significant shortcomings in the current smart city debates [44-46]. As regional cities may not possess the sufficient financial resources required for smart city initiatives, there is a need to better align smart city strategies with existing government policy and priorities to improve their funding capabilities $[47,48]$. By carefully evaluating local context before implementing smart city ideas, critical issues can be prioritised and addressed accordingly in a more cost- and time-efficient manner.

This review of the literature is fundamental to understanding the key themes and debates relating to smart cities. The literature review findings will be used as a basis for analysing a case study of the Gold Coast in terms of its key challenges and opportunities for developing into a smart city.

\section{Case Study of the Gold Coast}

As a coastal city with approximately half a million population, the Gold Coast is located on the south-eastern corner of the South East Queensland (SEQ) region, which also comprises Brisbane, Logan, and the Sunshine Coast, all of which have recently demonstrated an intent to develop into smart cities. Figure 1 below displays the location of the Gold Coast in relation to the nearby cities and regional areas from both the Queensland and New South Wales states. 


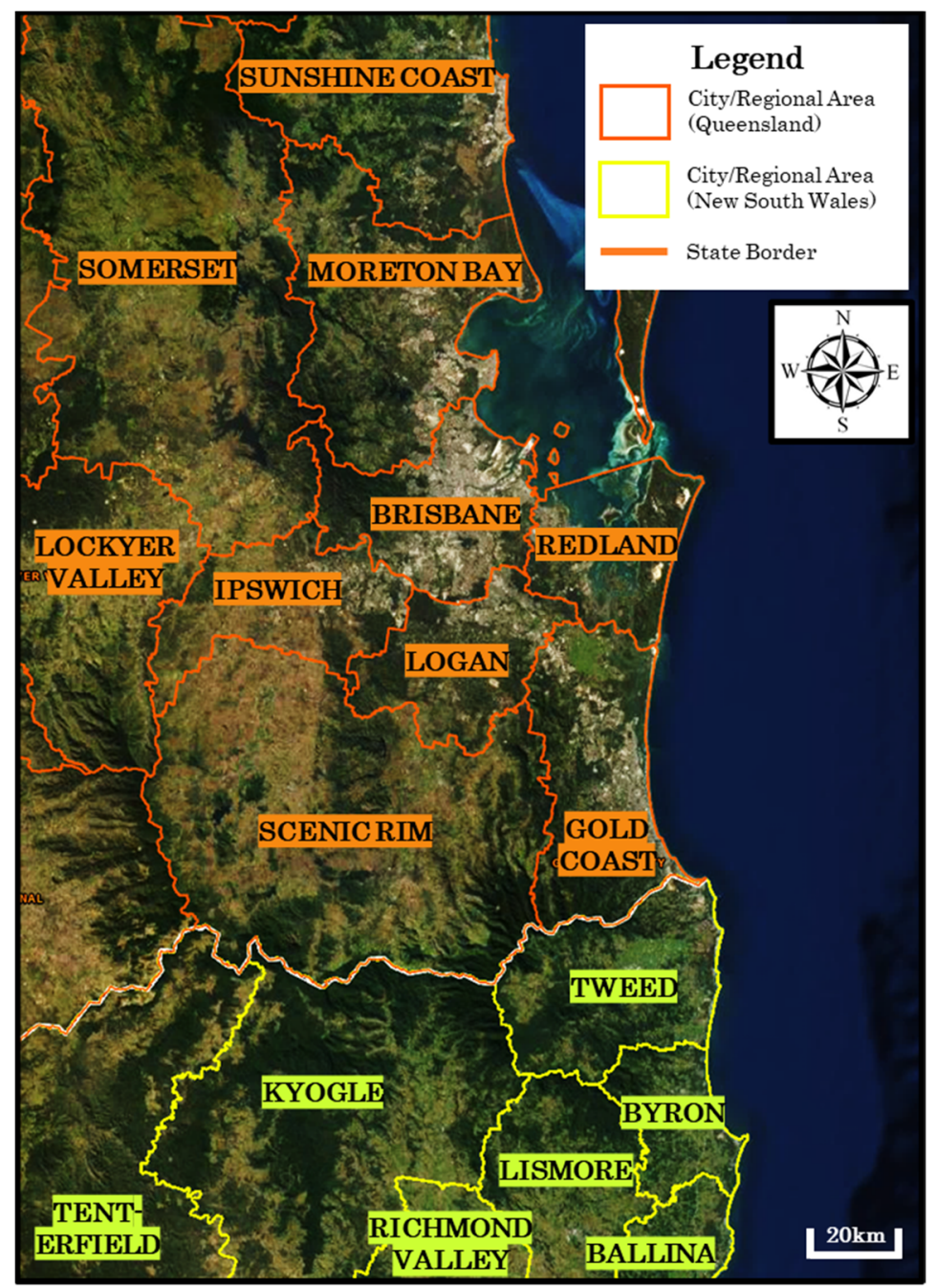

Figure 1. Map of the Gold Coast and its surrounding cities and regional areas, created by the authors using satellite imagery from Queensland Globe [49] under the CC BY 3.0 AU license [50].

The Gold Coast is the sixth-largest city in Australia, with an expected population figure of about three-quarters of a million by 2026 [51]. The city has a subtropical climate with more than 80 kilometres of beaches on the eastern end and hinterland on the western side. Characterised by a cluster of high-rise residential towers along the beaches, most of the Gold Coast's urban development and population are concentrated close to the coastline. Given the increasingly limited availability of land in coastal suburbs, the Gold Coast is currently experiencing suburban growth in inland outskirts, which is progressively constrained by the hinterland. With an extensive network of waterways acting as barriers to walking, cycling, and public transport, the Gold Coast is a car-dependent city. In recent years, there has been a constant need for expanding the Gold Coast's road infrastructure to accommodate its rapidly growing volume of vehicular traffic [52]. As such, the Gold Coast is facing a significant challenge for accommodating future growth in population, traffic congestion [53], and housing demand [54] in a sustainable manner. In response to this long-term challenge, the CoGC has specified an objective to transform the Gold Coast into an "active digital city" where "data and real-time information [are used] to shape [the] city" [55] (p. 14). As part of this objective, a sensor network will be installed to monitor and manage the local transport infrastructure. Additionally, real-time data will be increasingly used to support disaster responses, public safety, and other initiatives in the future.

The entire Gold Coast region is governed by the CoGC, making the council the secondlargest local government agency in Australia behind Brisbane regarding jurisdictional 
population size. Whilst tourism has historically been an important economic driver of the Gold Coast, it also has a foothold in other industries, including education, sports, film, marine, and ICTs. Accordingly, the council has recently displayed an intent to develop these industries further to improve the Gold Coast's profile as a major event destination [56]. Driven by the prospect of hosting the Commonwealth Games in 2018, the Gold Coast became the first city in Queensland to incorporate a light rail system into its public transport services. Partly funded by both the Federal and state governments, the project is identified as a successful example of the "Smart Infrastructure" pillar within the Smart Cities Plan launched in 2016 by the Federal Government, with the other two pillars underpinning the policy being "Smart Policy" and "Smart Technology" [57]. The Smart Cities Plan considers delivering infrastructure to not just capital cities but also for regional cities to support long-term growth. With the 2032 Olympic and Paralympic games confirmed to be hosted in SEQ and seven venues planned throughout the Gold Coast for the events [58], the city needs to utilise this major opportunity to address the planning challenges it is currently facing. Especially given that the SEQ City Deal is still under negotiation with the Federal Government after it was signed in March 2019 [59], the strategic priorities need to be carefully thought out for future-proofing the city in this context as interconnected smart cities at the regional level can be beneficial for stimulating the development of innovative and inclusive urban infrastructure networks [60]. City Deals involve a partnership between all government and community levels in driving long-term investment and economic growth for eight Australian cities/regions, one of which is SEQ.

Smart city initiatives by major Australian metropolitan cities, such as Sydney, Melbourne, and Brisbane, garner greater attention and benefit from legacy planning and federal funding [61]. Brisbane was recognised as one of the earliest proponents of smart city initiatives in the city-building process. Recently, Brisbane Vision 2031, the planning scheme for Brisbane, identifies "smart, prosperous city" as one of its eight themes [62]. In addition, the Smart, Connected Brisbane Framework focuses on Brisbane City Council's dedicated approach to enabling (a) user-centred design with clear goals and aspirations, (b) pathways to collaboration, (c) fit-for-purpose and future-proofed infrastructure, and (d) data usage for informed decision making [63]. Initiatives implemented under the framework include projects on smart poles and road safety, and innovative technology exploration in partnership with businesses, community, and universities.

On the other hand, the Gold Coast's smart city journey commenced with its participation in IBM's Smarter Cities Challenge as a grant recipient in 2013, but, beyond this milestone, the various smart city initiatives implemented for the city since then have been ad-hoc compared to other cities [56]. Similar regional cities in Australia, such as the Sunshine Coast and Newcastle, are early adopters of smart city strategies and have charted a more mature and unique approach. In particular, Newcastle has emerged with a strategic vision that does not focus on corporate images of smart cities but prioritises solutions for the local community's needs [64]. In comparison, the Gold Coast is still in a state of infancy in its transition to a smart city. Though, in recent times, the CoGC has been investing in several smart city initiatives under the "Our sustainable city" program [65]. However, there is still scope for a more co-ordinated approach. The SEQ City Deal proposition document places greater emphasis on Brisbane, while the Gold Coast light rail is the only project that the document highlights [66]. Additionally, in the case of Brisbane, advocacy groups such as the Committee for Brisbane, which includes representatives from businesses, industry bodies, and universities, publishes policy papers to position Brisbane as a highly liveable city [67]. A similar stakeholder arrangement is lacking for the Gold Coast. Therefore, more research and planning are needed to understand the unique challenges and opportunities for the Gold Coast's smart city transformation, thus motivating this study.

As previously shown in the literature review, the current concepts of smart cities are transitioning away from just a technology-centred approach towards a more holistic approach. Despite the lack of a universal definition, several researchers have proposed smart city frameworks to explain the emerging city model, e.g., [15,68-70]. Six key dimensions, 
including governance, economy, mobility, environment, people, and living, are recurring themes in some frameworks. For this article, we identified the following five thematic areas, developed in a previous study on the Gold Coast [71] and further expanded in this research, as essential considerations for smart cities:

1. Cultural and natural amenities-the various quality of life factors, such as public spaces, natural environment, events, and cultural activities and facilities.

2. Technology-implementation of ICTs and advanced telecommunication infrastructure for the improvement of city systems and services.

3. Knowledge and innovation precincts-facilities for attracting, creating, and retaining a knowledge workforce.

4. People and skills-attraction, creation, and retention of knowledge/creative workers and businesses.

5. Governance-e-governance, strategic plans, stakeholder collaboration, and open data, which are accessible to the public in real-time.

The themes above collectively form a conceptual framework of smart cities, which is visually displayed in Figure 2 below. The figure also illustrates some of the key factors underpinning each theme.

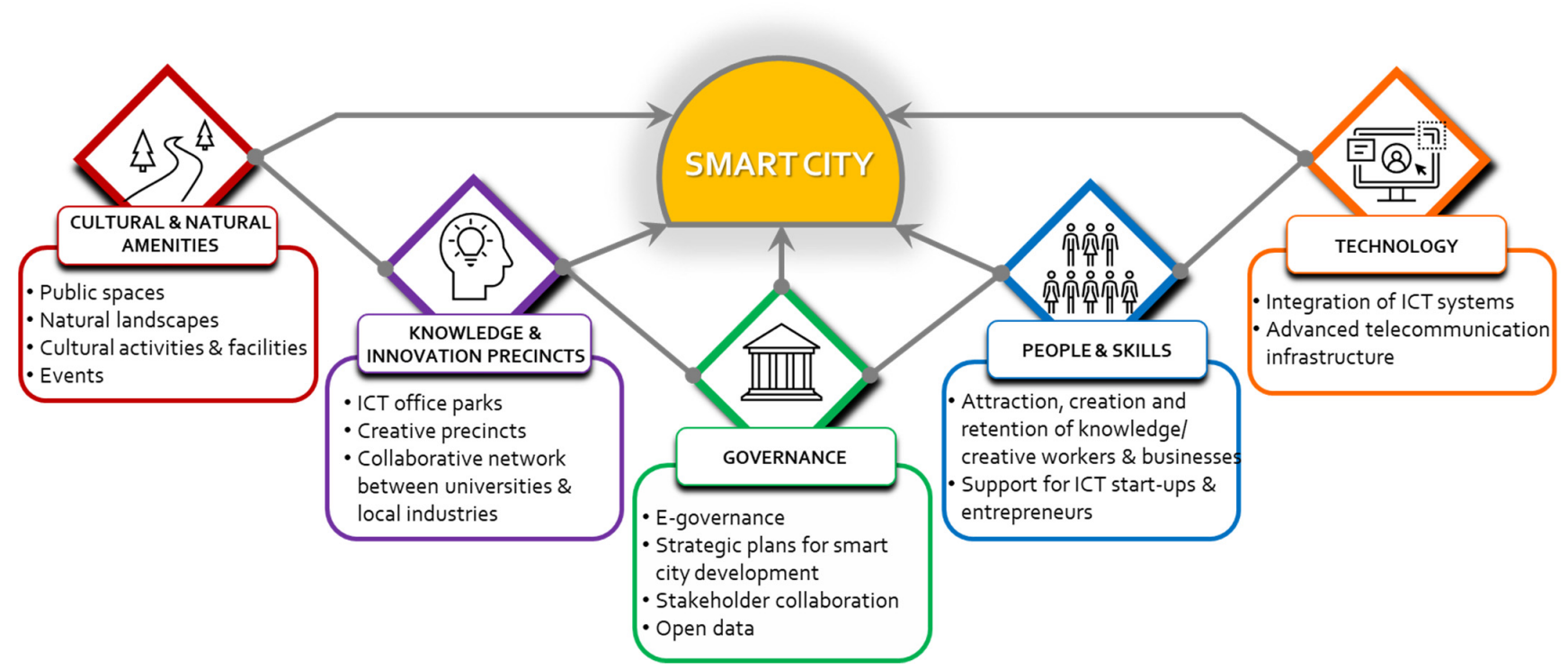

Figure 2. Key themes and factors for analysing the Gold Coast case study, adapted from [71].

The study applied the framework to the Gold Coast. Based on the five key themes articulated in the framework, opportunities and challenges for the Gold Coast to develop into a smart city were identified. The discussion below is primarily based on a critical analysis of the city's existing context and relevant policies and initiatives across both the public and private sectors.

\subsection{Cultural and Natural Amenities}

The first theme is related to the quality of life, which can be enhanced by factors such as natural environment, public spaces, events, and cultural activities and facilities. Importantly, a high quality of life can act as a key catalyst for attracting knowledge/creative workers, who are critical to creating a smart city.

The Gold Coast is promoted as a unique location with natural beauty and as an ideal place to live, work, and play. As one of Australia's most biologically diverse cities, the city is home to several World-Heritage-listed rainforests, coastal ecosystems, and worldrenowned beaches, which are frequented by both locals and visitors alike. The Gold Coast also comprises a range of entertainment facilities, such as theme parks and wildlife sanctuaries, sporting and exhibition facilities, recreational facilities, and outdoor activities. Nevertheless, the unique ecosystems within coastal cities like the Gold Coast are prone to 
natural hazard events. The CoGC has implemented some initiatives to mitigate these effects, which are further discussed in Section 3.2. However, there is still scope for introducing some of the emerging smart technologies and practices for coastal disaster management. Some of the prominent uses of technology for disaster management include ICT-based global and regional disaster alert systems, water-level monitoring through the use of sensors, early flood detection and processing closed-circuit television (CCTV) imagery for machine learning, foldable flood barriers, and transmission of disaster information to smartphones [72].

As part of the city's Culture Strategy 2023 vision, the first stage of Home of the Arts (HOTA), a new Cultural Precinct seeking to showcase the Gold Coast community's culture, arts, and creativity to the world, has been recently completed [73]. In addition to HOTA, several art galleries and museums are located throughout the city and have served as the city's popular attractions. Along with smaller events that are either free or low-cost, the city also regularly hosts several major events. The rich diversity and availability of natural environment, events, and entertainment and cultural facilities, which have all contributed to making the city one of Australia's most popular destinations, can play a major role in attracting knowledge/creative workers.

However, the Gold Coast's image and branding are often perceived poorly by the rest of the country due to issues with safety, drugs, bikers, and violence, which are also frequently overplayed by the media [74]. Meanwhile, swift population growth and the increasingly limited availability of greenfield land supply on the Gold Coast have led to high demand for new residential developments and rapidly rising housing prices [75]. Likewise, a recently conducted study on the supply of affordable rental housing revealed that the Gold Coast had the greatest shortage of affordable housing amongst large regional satellite cities in Australia [54]. Throughout the COVID-19 pandemic, this situation has further worsened with a large influx of interstate migration to the Gold Coast, adding to the strain on the supply of affordable rental housing [76]. The Gold Coast's negative image and lack of affordable housing could be a significant barrier to attracting knowledge/creative workers.

\subsection{Technology}

The technology theme is related to the use of ICTs to improve how the city operates and the availability of advanced telecommunication infrastructure. In addition to improving the efficiency of several city services, these technologies can play a vital role in attracting knowledge workers to a city. They can also support land use intensification policies to address land supply shortages and their associated issues such as traffic congestion and lack of housing affordability.

The CoGC, through its Local Government Infrastructure Plan and Economic Development Strategy 2013-2023, promotes smart infrastructure development in three key areas, namely, climate change response infrastructure, transport infrastructure, and ICT transformation [77]. As a city prone to a rising sea level, coastal erosion, and other climate change issues, the CoGC utilised the IBM Smarter Cities Challenge grant as a measure to improve its climate change resilience and response capabilities. The establishment of the Transport Coordination Centre during the 2018 Commonwealth Games [78] has improved the efficiency and attractiveness of the local public transport infrastructure by providing real-time information. Likewise, the recently implemented ICT Transformation Program has enhanced the council's digital customer service capabilities [77].

The CoGC has recently implemented a range of ICTs to improve the operational efficiency of the city's infrastructure. Wireless sensors have been installed at Springbrook National Park, a 6725-hectare World-Heritage-listed rainforest, to monitor environmental variables and track biodiversity restoration [79]. The Gold Coast Waterways Authority manages and protects the 260-kilometre stretch of navigable inland waterways throughout the city. In early 2020, the agency collaborated with the Queensland University of Technology and invested in a smart camera trial to study the waterways. The trial will use machine learning and statistical analysis to investigate the type of vessels using the waterways 
and to document marine incidents and weather conditions [80]. The CoGC has invested in several water infrastructure solutions to improve the city's water resilience. Drinking water quality and safety are ensured through regular testing and sampling, the results of which can be accessed by the public using the online interactive mapping tool [81]. Since June 2020, the council has been upgrading existing water meters with smart metering devices that can collect, transmit and analyse water-usage data. The CoCG envisages "access to near real-time water-use data" for non-residential users in the first stages of the smart water meter project [82].

The mid-life review of Gold Coast Transport Strategy 2031 identified traffic congestion management as one of the key priorities. In addition to the major road and intersection upgrades proposed, the review recognised opportunities for employing ICTs to gather and share real-time traffic information, monitor incidents, and coordinate traffic control [52]. As part of the strategy, the CoGC has implemented two fully automated parking-enforcement units. The vehicle-mounted units employ cloud-based, preloaded parking rules and include automatic license-plate-recognition cameras.

In December 2020, the Gold Coast became the first city in Queensland to incorporate smart ticketing into its public transport system. The project has enabled payments for trips to be made using smartphones, smartwatches, or debit/credit cards, effectively replacing existing card- and ticket-based systems [83]. By increasing the convenience of using public transport, the smart ticketing system will expectedly drive the city's public transport patronage, which has substantially expanded following the recent introduction of the light rail [84]. Stage 2 of the light rail was completed in December 2017 ahead of the 2018 Commonwealth Games, and two additional stages are planned for further expansion of the infrastructure. Enhancing the use of public transport will aid in reducing the amount of land and investment required for accommodating vehicular traffic in the future, thus assisting in land-use intensification for the city. In addition, the CoGC has invested in renewable energy technology for sustainable transport options. The installation of ten electrical charging stations in 2021 [85], an example of which is shown in Figure 3 below, demonstrates the council's intent to promote the use of alternative fuel vehicles on the Gold Coast.

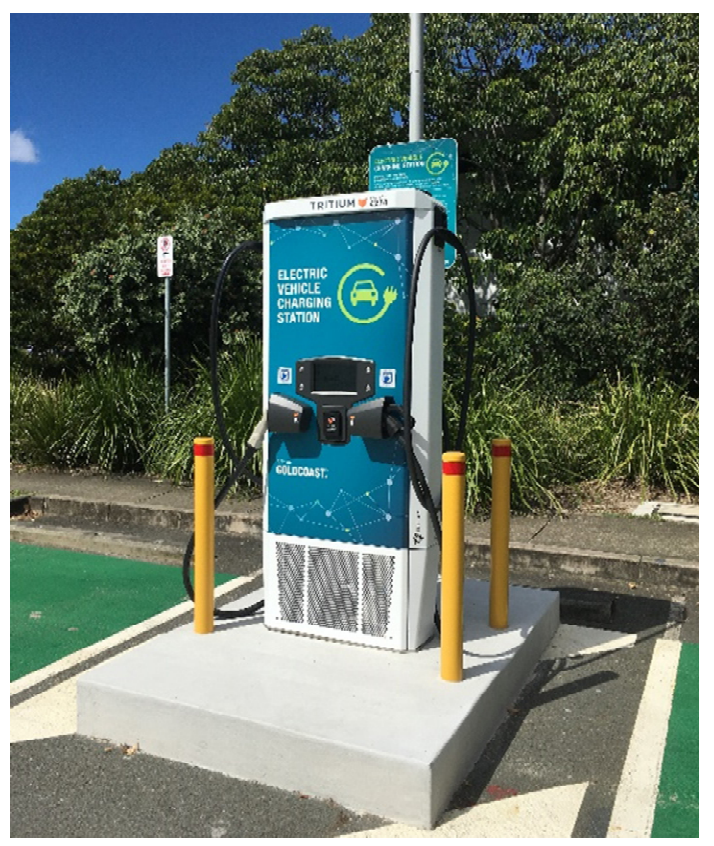

Figure 3. An electric vehicle charging station at HOTA (source: authors).

A major telecommunication infrastructure in Australia, which has received significant political, public, and media attention over the past decade, is the National Broadband 
Network (NBN). As at September 2021, most of the urban areas of the Gold Coast are serviced by fixed-line NBN infrastructure [86]. The NBN was expected to provide highspeed broadband access to all Australian households [87], yet its average internet speed is one of the lowest amongst OECD countries [88]. Most Australian cities, including the Gold Coast, have experienced a high level of internet congestion and the resulting lower internet speed throughout the COVID-19 pandemic [89] due to the increased adaptation of remote working from home induced by government-imposed lockdowns [90]. Cities like Adelaide have invested in enterprise-grade fibreoptic networks to establish the "Ten Gigabit Adelaide" network for seamless and high-speed internet connection [91]. Likewise, several other regional cities in Australia have made similar investments to attract businesses (e.g., Bendigo, with its 100-gigabit network [92] and the Sunshine Coast, through the international submarine cable connected to its "new Gigabit Maroochydore City Centre" project [93]). As part of its objective to transform the Gold Coast into an active digital city, the CoGC has recently invested in a range of infrastructure to facilitate digital connectivity for the city. Table 1 below outlines the range of existing and developing digital infrastructure on the Gold Coast.

Table 1. Summary of digital infrastructure on the Gold Coast, adapted from [94].

\begin{tabular}{|c|c|}
\hline Infrastructure Type & Details \\
\hline Internet of Things & $\begin{array}{l}\text { Installation of a commercial-grade low-power wide-area network (LPWAN), which enables } \\
\text { large-scale Internet-of-Things (IoT) applications and encompasses more than } 1300 \mathrm{~km}^{2} \text {. }\end{array}$ \\
\hline Telecommunications & $\begin{array}{l}\text { - Council-invested telecommunications network, which is expected to enhance local internet } \\
\text { speeds and enable the council to keep rates low. }\end{array}$ \\
\hline Fibreoptic network & $\begin{array}{l}\text { - The CoGC is the first council in Australia to invest in an 864-core carrier-grade fibreoptic } \\
\text { network, covering more than } 95 \mathrm{~km} \text {; } \\
\text { Provision of } 1 \text { gigabit-per-second internet speed in the Gold Coast Health and Knowledge } \\
\text { Precinct, further discussed below, and additional locations in the future. }\end{array}$ \\
\hline Free Wi-Fi & $\begin{array}{l}\text { Provision of free Wi-Fi for residents, visitors, and local businesses in the major urban } \\
\text { centres of the city. }\end{array}$ \\
\hline Data intelligence & $\begin{array}{l}\text { - Digital City Insights (DCI) - a council initiative utilising data collection, research, and analysis } \\
\text { to develop new insights for guiding the council and local businesses [95]. }\end{array}$ \\
\hline Open data portal & $\begin{array}{l}\text { - Availability of Geographic Information System (GIS) data on the council's Open Data Portal } \\
\text { for public use; } \\
\text { Published datasets include information on council administration, local environment, parks and } \\
\text { recreation, planning and building, stormwater, transport, and water and sewerage services. }\end{array}$ \\
\hline Mobile app & - City App—the CoGC's mobile application for access to online council services. \\
\hline
\end{tabular}

The CoGC's investment in telecommunications and fibreoptic networks will crucially support working-from-home arrangements both throughout and post the COVID-19 pandemic. As such, the infrastructure can potentially play an important role in land-use intensification in the future, thus addressing the city's land use supply issue previously discussed.

The CoGC's investment in a range of relevant technologies to create digital connectivity for the Gold Coast illustrates the council's proactive approach to ensuring adequate telecommunication infrastructure in line with its corporate plan. However, with increasing competitiveness amongst other regional cities for digital connectivity dominance, it is relevant that the Gold Coast continues to upgrade its digital infrastructure to stay ahead. This can be challenging, however, as the council has been reducing its yearly rate increases since 2012. The city's rates are the second-largest source of income for the council, contributing to approximately one-third of the budget [96]. Additionally, limited funding could be available for future smart city initiatives, especially in the post-pandemic period. 


\subsection{Knowledge and Innovation Precincts}

The third theme applied to the case study is associated with knowledge and innovation precincts, which play a critical role in attracting, nurturing, and retaining knowledge/creative workers.

Several ICT office parks are located throughout the Gold Coast and specifically cater to the needs of ICT businesses. As part of the CoGC's Pacific Innovation Corridor strategy, Varsity Lakes, a master-planned community adjoining Bond University, has been designated as a specialised ICT hub with offices for ICT businesses. In addition to Varsity Lakes, Southport, the city's central business district, has been designated as another ICT hub.

The Gold Coast is also home to Village Roadshow Studios, a creative precinct providing world-class film production facilities where several film companies are jointly located. With various film equipment and facilities available on-site, the precinct's primary competitive advantage is its relatively higher cost-effectiveness for film production than other major filming locations such as Los Angeles. The CoGC [97] (p. 11) describes the Gold Coast as "an enviable [filming] location for any production company" due to Village Roadshow Studios, easily accessible and diverse locations, and readily available production crews who are experienced in both film and television. The CoGC is also the only local government agency in Australia to offer financial and non-financial incentives to attract film and television productions to the city through its Screen Attraction Program. To date, several high-profile films and television series have been produced on the Gold Coast (e.g., Aquaman, Thor: Ragnarok, San Andreas, Peter Pan, and Terra Nova).

The Queensland Government has recently established the 200-hectare Gold Coast Health \& Knowledge Precinct (GCHKP) in Southport. The mixed-use precinct comprises Gold Coast University Hospital, Gold Coast Private Hospital, a co-working and innovation hub, a residential precinct, and a Griffith University campus. In addition to the GCHKP, the other two universities on the Gold Coast are also co-located with hospitals. Bond University is situated in proximity to Robina Hospital. On the other hand, two major hospitals, namely, John Flynn Private Hospital and Tweed Hospital, adjoin Southern Cross University's Gold Coast campus. The three universities have been collaborating with their nearby hospitals to provide practical experience for their medical students. The co-location of the universities and the hospitals throughout the Gold Coast not only promotes the city as a desirable location for medical studies but also locally generates knowledge workers in the healthcare industry.

Another major knowledge precinct, which plays an important role in attracting and generating knowledge workers for the city, is centred around the Southern Cross University campus. The campus is located inside Gold Coast Airport, one of the fastest-growing airports in Australia. This co-location of an airport and a university campus is the first of its kind in Australia as of 2018 [98]. The knowledge precinct has significant knowledge creation implications for the Gold Coast as the airport attracts fly-in/fly-out students both domestically and internationally [99].

However, due to the historically car-oriented design of the Gold Coast, there is currently a lack of direct connectivity, particularly by walking, cycling, and public transport, between its knowledge precincts [100]. Enhancing the connectivity between the precincts could facilitate further training for students and additional collaborative initiatives between the universities and the hospitals. The recently implemented smart ticketing system for the local public transport and the light rail, both previously discussed, will play a critical role in promoting public transport connectivity between these knowledge precincts. The planned installation of a sensor network across the city's transport network will aid in alleviating traffic congestion and reduce travelling time, thus assisting in strengthening the transport connectivity between the knowledge precincts.

\subsection{People and Skills}

The article now examines the theme of people and skills associated with attracting, creating, and retaining knowledge/creative workers and businesses in a city. 
Gold Coast TechSpace, a community innovation hub, regularly delivers workshops for local communities to learn about different technologies, such as robotics, green technologies, and a range of hardware and software. It also provides different memberships to cater to a range of interests and needs amongst community members. The organisation plays a significant role in educating local ICT workers for the city. The Gold Coast Innovation Hub, a not-for-profit organisation established in 2017 through a partnership of several stakeholders, provides physical and virtual co-working spaces to connect and support startups and foster the "innovation ecosystem" of the Gold Coast [101]. Likewise, in partnership with Telstra and other ICT companies, the CoGC launched the Mayor's Telstra Technology Award in 2014. The event, which has been running on an annual basis, invites high-school students to submit innovative ideas for new technology products. During the competition, students are mentored by representatives from Bond University, Telstra, and Startup Apprentice to transform their initial ideas into a concrete plan [102]. Startup Apprentice, a local organisation recently established in response to the high youth unemployment issue in the city, has been providing after-school entrepreneurship education to local students. It aims to equip students with entrepreneurship. The Mayor's Telstra Technology Award and Startup Apprentice play an important role in nurturing young, local entrepreneurs for the city.

In recent years, the CoGC has implemented several initiatives to attract international students to the Gold Coast. The council currently has active Sister City Agreements for student exchange programs with cities in China, the United Arab Emirates, the United States, Japan, Taiwan, and New Caledonia [103]. However, in contrast to metropolitan cities in Australia, the Gold Coast has a relatively limited range of employment options due to its dependence on tourism and associated industries. The relative scarcity of the Gold Coast's employment opportunities may constrain the city's ability to attract and retain tertiary students and knowledge/creative workers.

\subsection{Governance}

The article now examines the theme of governance, which relates to e-governance and strategic plans, stakeholder collaboration, and the availability of real-time open data.

Smart city policy at the local government level has been gaining prominence in Australia, with several cities implementing smart city strategies in addition to state-level policies [61]. For instance, Brisbane City Council launched its "Smart, Connected Brisbane Framework" [63], outlining its vision for achieving goals for Brisbane using innovation, technology, and data. The Sunshine Coast Regional Council [104] adopted the Sunshine Coast Smart city framework in 2016 and set out the Smart City Implementation plan 2016-2019. Likewise, in 2018, Logan City Council released its City Futures Strategy, a smart city plan which is aligned with the Smart Cities Plan and the council's other strategic plans [105]. In contrast, the CoGC has not yet implemented a specific smart city strategy or framework. The Corporate Plan-Gold Coast 2022, which highlights the council's strategic directions for the Gold Coast, identifies a few key plans and programs to realise the outlined objective of becoming an active digital city [55], without underlining specific strategies or implementation plans. This objective centrally focuses on the use of technology to shape and manage the city. The other themes critical to the creation of a smart city-namely, cultural and natural amenities, knowledge and innovation precincts, and people and skillshave not been addressed in the corporate plan for the purpose of transforming the Gold Coast into a smart city. As such, the objective does not sufficiently integrate the different elements of smart cities in its current state.

The smart city objective in the CoGC's corporate plan has not been adequately integrated into the strategic framework of the City Plan, the council's planning scheme regulating land uses throughout the Gold Coast. Without sufficient incorporation of smart city directions into the City Plan, future development driven by the private and community sectors may inhibit the Gold Coast's evolution into a smart city. In contrast, Brisbane's planning scheme articulates the establishment of the city as a "smart, prosperous city" as a 
central theme. The document specifies that "Brisbane's highly-skilled workers will be a major competitive advantage for local businesses and attract new businesses to the city" and that, by 2031, Brisbane will be "a major Australian study destination for international students" [62].

The Gold Coast is one of the first three Australian cities to participate in the Open \& Agile Smart Cities (OASC) initiative, along with Brisbane and Springfield [106]. OASC is an international collaborative program comprising more than 150 cities from around the globe as of December 2020, according to the OASC's website. The initiative seeks to promote the development of smart cities using standard Application Programming Interfaces (APIs) and datasets amongst member cities. Through its Open Data project, the CoGC provides access to a broad range of GIS data through its online Open Data Portal. However, in an Open Data Forum event recently hosted by the CoGC, data ownership has been highlighted by local ICT businesses as a major barrier to creating innovative information products for the public. Whilst some datasets are under the council's ownership, others are exclusively owned by other government agencies, thus preventing adequate access. The CoGC has also been actively collaborating with several businesses to spearhead the development of the city's knowledge industry, infrastructure, and workers. For instance, the council has been working with CoastalCOMS, a local ICT firm, in monitoring the city's beach conditions and is a Founding Partner for TechSpace. The Open Data project, which can encourage innovative information products and services to be created by individuals and businesses, also heavily involves the private sector to ensure a comprehensive data range is available to the public.

The CoGC has implemented some e-governance initiatives for more efficient city management and to improve the accessibility of its services to the public. The council released a smartphone app named "City App" in 2019, which functions as a central point of communication for local citizens and visitors to report non-urgent issues throughout the city, such as graffiti, illegal dumping of rubbish, water leaks, and abandoned vehicles. It also allows photos taken with smartphones to be attached to a report. However, as of 10 September 2021, the app has attracted poor ratings on both Apple's App Store (2.1 out of the possible 5 stars) and Google's Play Store (1.9 out of 5), with reviews highlighting issues associated with the app's layout, navigation, and functions. Another e-governance initiative of the CoGC is related to its rates and water bills, which were previously only mailed to residents in a paper format. The council's website now enables residents to instantly update their contact details and view and pay their rates and water bills.

The CoGC has a community engagement program to facilitate and encourage public participation in generating ideas for shaping the city's future. The council also has an online platform titled "GC have your say," where residents can share their opinions on its draft strategies and policies. In addition, the platform allows residents to provide feedback on development applications requiring public notification before the council's decision is made. In recent years, local Gold Coast community members have been involved in providing feedback on several plans and policies, such as the Gold Coast City Transport Strategy 2031, the Culture Strategy 2023, and amendments to the City Plan. However, the majority of community engagement undertaken by the council has historically been initiated at the stage when a draft plan has been finalised. This process inherently limits the ability of local community to shape the council's plans and policies. Alternatively, if community members were engaged at an earlier stage of the plan-making process, their ideas would influence these documents and the future of their city to a greater extent [107].

Figure 4 below summarises the opportunities and challenges for developing the Gold Coast into a smart city.

The dotted lines between the five themes in Figure 4 above reflect the ad hoc nature of the Gold Coast's smart city development to date. The CoGC has been proactive in developing the city into a smart city, evident from its implementation of several initiatives that complement the different smart city themes in Figure 4. However, the existing strategic objective for the city to become a digital city primarily considers the technology dimension 
of smart cities. As such, there is an opportunity to holistically integrate all five smart city dimensions outlined in Figure 4 across the relevant strategic and statutory planning frameworks for the Gold Coast. There is also an opportunity to systematically assess the potential of smart city ideas and ICTs to contribute to each of the five themes and to the suggested integration of the themes. Capitalising on these opportunities will enable future initiatives, investment, and development on the Gold Coast to support, rather than inhibit, the city in its transformation into a smart city.

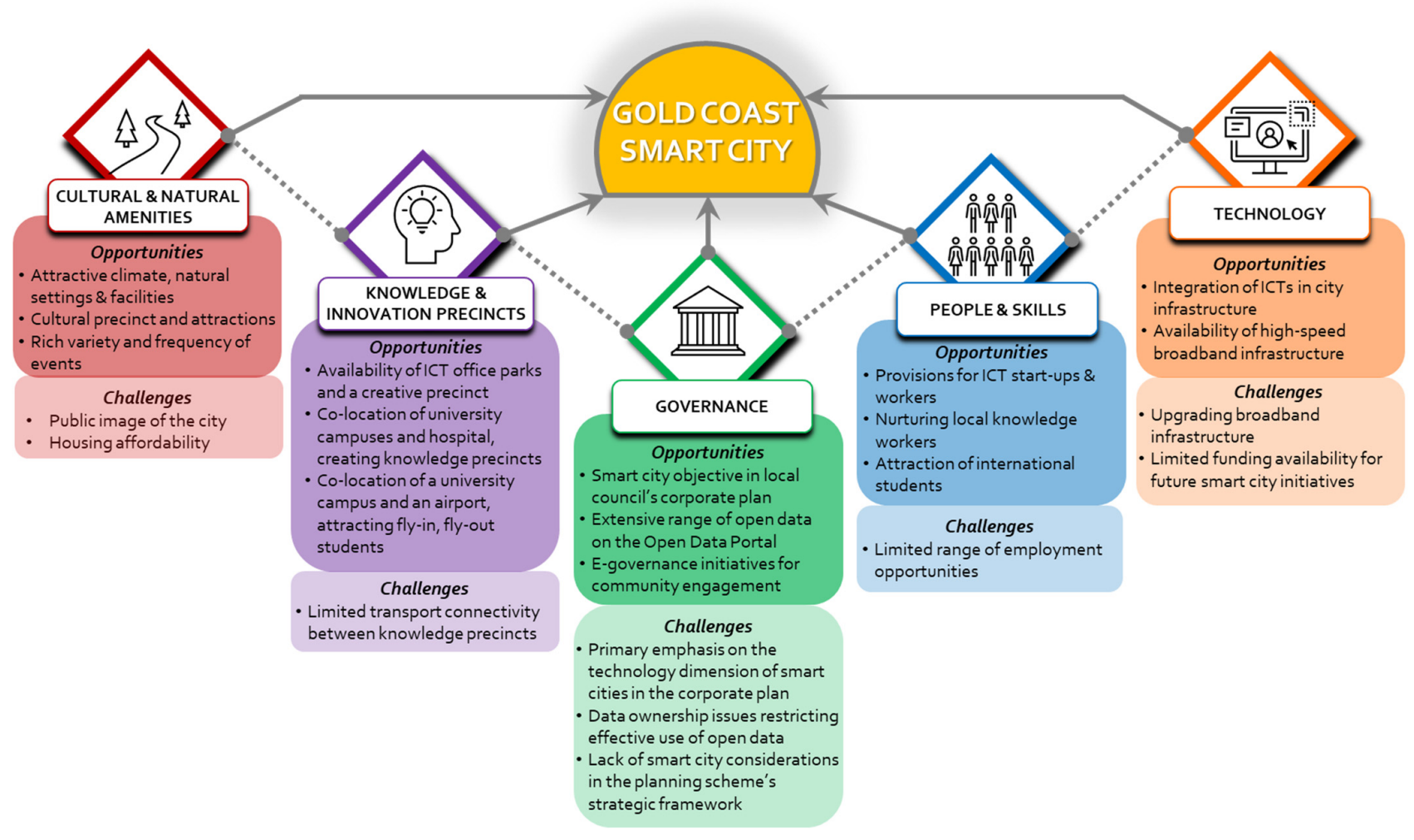

Figure 4. Opportunities and challenges for developing the Gold Coast into a smart city.

\section{Conclusions}

As cities continue to become increasingly globalised and competitive and move towards the knowledge and information economy, the concept of smart cities is gaining worldwide traction. This study examined the nature of smart cities through a literature review, which revealed five important dimensions of smart cities, including: cultural and natural amenities, technology knowledge and innovation precincts, people and skills, and governance. These factors were organised into themes, which collectively form a conceptual framework of smart cities. The framework was then applied to the case study of Australia's Gold Coast, a regional city still in its infancy in its smart city journey, to identify key challenges and opportunities for its development into a smart city. The following seven key lessons for developing regional cities into smart cities can be drawn from the case study:

(1) The Gold Coast's successful bid for hosting the 2018 Commonwealth Games helped the city to attract external investments in smart infrastructure such as IBM's Smarter Cities Challenge grant and the city's light rail infrastructure, which received state and federal funding support. The 2032 Olympics and Paralympics provide another excellent opportunity to attract funding in smart infrastructure for both the Gold Coast and the whole SEQ region. The Gold Coast's success in securing funding by leveraging a major international event is an example that other regional cities can follow in attracting external investment for smart city initiatives. 
(2) Cultural and natural amenities play an important role in attracting and retaining knowledge workers, particularly for regional cities, as they may lack the "pull factors" that metropolitan cities often do. The nature of these amenities can be tangible (e.g., entertainment and lifestyle amenities, natural landscapes, and cultural precincts) or intangible (e.g., city's image and branding and housing affordability).

(3) Ensuring widespread availability of high-speed internet infrastructure is essential for supporting remote-working arrangements, which have become critically important throughout the COVID-19 pandemic, and for improving global competitiveness of cities. Future-proofing digital infrastructure is especially relevant before a major event such as the Olympic Games 2032, which has long-term planning implications for the Gold Coast.

(4) The partnership between a university and state and local governments to establish the Gold Coast Health \& Knowledge Precinct has strengthened the Gold Coast's healthcare and education industries. Other regional cities can apply a similar partnership arrangement to diversify their economic bases and attract knowledge workers.

(5) Government-collected data related to the natural and built environments should be made available to the public in real-time. However, when publishing this data, issues associated with data ownership should be addressed to allow local stakeholders to efficiently access and utilise the data and to create useful information products and services for the public.

(6) Planners should ensure that smart city directions articulated in strategic plans are adequately reflected in the city's land-use regulations. By doing so, future development will become more aligned with smart city objectives, which could assist in expediting the overall process of smart city development. The SEQ City Deal also provides a significant opportunity for coherently strategising the region's future priorities, including smart city developments for the Gold Coast and other cities in the region.

(7) Planning frameworks should holistically integrate the different elements of smart cities. The current strategic objective for the Gold Coast to become a digital city places a strong emphasis on the technology dimension of smart cities. However, other dimensions highlighted in this study, including cultural and natural amenities, knowledge and innovation precincts, people and skills, and governance, are also important considerations for developing smart cities.

These lessons have potential applicability to not only the Gold Coast but also other emerging regional smart cities around the world.

Author Contributions: Conceptualisation, I.K. and B.B.; methodology, I.K. and B.B.; validation, B.B.; formal analysis, I.K.; investigation, I.K.; data curation, I.K. writing一original draft preparation, I.K.; writing-review and editing, I.K., K.S.C. and B.B.; visualisation, K.S.C.; supervision, B.B.; project administration, I.K. and B.B. All authors have read and agreed to the published version of the manuscript.

Funding: This research received no external funding.

Conflicts of Interest: The authors declare no conflict of interest.

\section{References}

1. Bibri, S.E.; Krogstie, J. The Emerging Data-Driven Smart City and Its Innovative Applied Solutions for Sustainability: The Cases of London and Barcelona. Energy Inform. 2020, 3, 1-42. [CrossRef]

2. Joo, Y.M.; Tan, T.-B. Smart Cities in Asia: Governing Development in the Era of Hyper-Connectivity; Edward Elgar Publishing Limited: Cheltenham, UK, 2020; ISBN 978-1-78897-287-1.

3. Deakin, M. Smart Cities: The State-of-the-Art and Governance Challenge. Theor. Chem. Acc. 2014, 1, 1-16. [CrossRef]

4. Hu, R. Australia's National Urban Policy: The Smart Cties Agenda in Perspective. Aust. J. Soc. Issues 2020, 55, 201-217. [CrossRef]

5. Dedekorkut-Howes, A.; Bosman, C. The Gold Coast: Australia's Playground? Cities 2015, 42, 70-84. [CrossRef]

6. Dedekorkut-Howes, A.; Bosman, C.; Leach, A. Considering the Gold Coast. In Off the Plan: The Urbanisation of the Gold Coast; Dedekorkut-Howes, A., Bosman, C., Leach, A., Eds.; CSIRO Publishing: Clayton, Australia, 2016; pp. 1-16. ISBN 978-1-4863-0183-6.

7. Gold Coast Tourism Advisory Panel. Gold Coast Global Tourism Hub: Community and Stakeholder Consultation; Queensland Government, 2019. Available online: https:/ / bit.ly /3Cuuv7Q (accessed on 20 July 2021). 
8. Cunningham, S.; McCutcheon, M.; Hearn, G.; Ryan, M.D.; Collis, C. Australian Cultural and Creative Activity: A Population and Hotspot Analysis: Gold Coast; Digital Media Research Centre, 2019. Available online: https://bit.ly/3EJh31K (accessed on 20 July 2021).

9. CoGC. Annual Plan 2016-17; CoGC, 2016. Available online: https:/ / bit.ly/3CB5mbA (accessed on 24 July 2021).

10. Allam, Z.; Newman, P. Redefining the Smart City: Culture, Metabolism and Governance. Smart Cities 2018, 1, 4-25. [CrossRef]

11. Angelidou, M. Smart City Policies: A Spatial Approach. Cities 2014, 41, S3-S11. [CrossRef]

12. Kitchin, R. The Real-Time City? Big Data and Smart Urbanism. GeoJournal 2014, 79, 1-14. [CrossRef]

13. Townsend, A.M. Smart Cities: Big Data, Civic Hackers, and the Quest for a New Utopia; W.W.Norton: New York, NY, USA, 2014; ISBN 978-0-3933-4978-8.

14. Hollands, R.G. Will the Real Smart City Please Stand Up?: Intelligent, Progressive or Entrepreneurial? City 2008, 12, 303-320. [CrossRef]

15. Albino, V.; Berardi, U.; Dangelico, R.M. Smart Cities: Definitions, Dimensions, Performance, and Initiatives. J. Urban Technol. 2015, 22, 3-21. [CrossRef]

16. Vanolo, A. Smartmentality: The Smart City as Disciplinary Strategy. Urban Stud. 2014, 51, 883-898. [CrossRef]

17. Barlow MMichael, A.; Lévy-Bencheton, C. Smart Cities, Smart Future: Showcasing Tomorrow; John Wiley \& Sons, Incorporated: Newark, NJ, USA, 2018; ISBN 978-1-1195-1618-7.

18. Toli, A.M.; Murtagh, N. The Concept of Sustainability in Smart City Definitions. Front. Built Environ. 2020, 6, 1-10. [CrossRef]

19. Anthopoulos, L.G.; Vakali, A. Urban Planning and Smart Cities: Interrelations and Reciprocities. In The Future Internet FIA 2012 Lecture Notes in Computer Science; Álvarez, F., Cleary, F., Dara, P., Domingue, J., Galis, A., Garcia, A., Gavras, A., Karnourskos, S., Schaffers, S.K., Li, M.-S., et al., Eds.; Springer: Berlin/Heidelberg, Germany, 2012; p. 1. Available online: https://bit.ly/2UX8vmc (accessed on 28 August 2021).

20. Yigitcanlar, T.; Lee, S.H. Korean Ubiquitous-Eco-City: A Smart-Sustainable Urban Form or a Branding Hoax? Technol. Forecast. Soc. Chang. 2014, 89, 100-114. [CrossRef]

21. Ferraris, A.; Santoro, G.; Pellicelli, A.C. “Openness” of Public Governments in Smart Cities: Removing the Barriers for Innovation and Entrepreneurship. Int. Entrep. Manag. J. 2020, 16, 1259-1280. [CrossRef]

22. Alizadeh, T. An Investigation of IBM's Smarter Cities Challenge: What Do Participating Cities Want? Cities 2017, 63, 70-80. [CrossRef]

23. Bibri, S.E. On the Sustainability of Smart and Smarter Cities in the Era of Big Data: An Interdisciplinary and Transdisciplinary Literature Review. J. Big Data 2019, 6, 25. [CrossRef]

24. Chandrasekar, K.S.; Bajracharya, B.; O'Hare, D. A Comparative Analysis of Smart City Initiatives by China and India: Lessons for India. In Smart Cities for 21st Century Australia-How Urban Design Innovation Can Change our Cities. In Proceedings of the International Urban Design Conference, Canberra, Australia, 7-9 November 2016; pp. 339-357.

25. Shelton, T.; Zook, M.; Wiig, A. The 'Actually Existing Smart City'. Camb. J. Reg. Econ. Soc. 2015, 8, 13-25. [CrossRef]

26. Hollands, R.G. Critical Interventions into the Corporate Smart City. Camb. J. Reg. Econ. Soc. 2015, 8, 61-77. [CrossRef]

27. Masik, G.; Sagań, I.; Scott, J.W. Smart City Strategies and New Urban Development Policies in the Polish Context. Cities 2021, 108, 102970. [CrossRef]

28. Ahvenniemi, H.; Huovila, A.; Pinto-Seppä, I.; Airaksinen, M.; Pinto-Seppa, I.; Airaksinen, M. What Are the Differences between Sustainable and Smart Cities? Cities 2017, 60, 234-245. [CrossRef]

29. Yigitcanlar, T. Technology and the City: Systems, Applications and Implications; Taylor and Francis: Milton Park, UK, 2016; ISBN 978-1-1388-2670-0.

30. Thomas, V.; Wang, D.; Mullagh, L.; Dunn, N. Where's Wally? In Search of Citizen Perspectives on the Smart City. Sustainability 2016, 8, 207. [CrossRef]

31. Tan, S.Y.; Taeihagh, A. Smart City Governance in Developing Countries: A Systematic Literature Review. Sustainability 2020, 12, 899. [CrossRef]

32. Nam, T.; Pardo, T.A. Conceptualizing Smart City with Dimensions of Technology, People, and Institutions. In Proceedings of the 12th Annual International Conference on Digital Government Research, College Park, MD, USA, 12-15 June 2011 ; pp. $282-291$.

33. Clement, D.J.; Crutzen, P.N. How Local Policy Priorities Set the Smart City Agenda. Technol. Forecast. Soc. Chang. 2021, 171, 1-11. [CrossRef]

34. Paskaleva, K. E-Governance as an Enabler of the Smart City. In Smart Cities: Governing, Modelling and Analysing the Transition; Deakin, M., Ed.; Routledge: London, UK, 2014; ISBN 978-0-4156-5819-5.

35. Angelidou, M. Strategic Planning for the Development of Smart Cities. Ph.D. Dissertation, Aristotle University of Thessaloniki, Thessaloniki, Greece, 2015. Available online: https:/ / bit.ly/3j1Qw5P (accessed on 1 July 2021).

36. Yigitcanlar, T. Smart Cities: An Effective Urban Development and Management Model? Aust. Plan. 2015, 52, 27-34. [CrossRef]

37. Datta, A. New Urban Utopias of Postcolonial India: “Entrepreneurial Urbanization” in Dholera Smart City, Gujarat. Dialogues Hum. Geogr. 2015, 5, 3-22. [CrossRef]

38. Watson, V. The Allure of "Smart City" Rhetoric: India and Africa. Dialogues Hum. Geogr. 2015, 5, 36-39. [CrossRef]

39. Komninos, N. Intelligent Cities: Variable Geometries of Spatial Intelligence. Intell. Build. Int. 2011, 3, 172-188. [CrossRef]

40. Grossi, G.; Pianezzi, D. Smart Cities: Utopia or Neoliberal Ideology? Cities 2017, 69, 79-85. [CrossRef] 
41. Glasmeier, A.K.; Nebiolo, M. Thinking about Smart Cities: The Travels of a Policy Idea That Promises a Great Deal, But So Far Has Delivered Modest Results. Sustainability 2016, 8, 1122. [CrossRef]

42. Saunders, T.; Baeck, P. Rethinking Smart Cities from the Ground up; Nesta, 2015. Available online: https://bit.ly/31Qz7yi (accessed on 17 June 2021).

43. Gehl, J. Cities for People; Island Press: Washington, DC, USA, 2010; ISBN 978-1-5972-6573-7.

44. Neirotti, P.; De Marco, A.; Cagliano, A.C.; Mangano, G.; Scorrano, F. Current Trends in Smart City Initiatives: Some Stylised Facts. Cities 2014, 38, 25-36. [CrossRef]

45. Kitchin, R. Making Sense of Smart Cities: Addressing Present Shortcomings. Camb. J. Reg. Econ. Soc. 2015, 8, 131-136. [CrossRef]

46. Esposito, G.; Clement, J.; Mora, L.; Crutzen, N. One Size Does Not Fit All: Framing Smart City Policy Narratives within Regional Socio-Economic Contexts in Brussels and Wallonia. Cities 2021, 118, 1-14. [CrossRef]

47. Alizadeh, T.; Sipe, N. Vancouver's Digital Strategy: Disruption, New Direction, or Business as Usual? Int. J. E-Plan. Res. 2016, 5, 1-15. [CrossRef]

48. Joss, S.; Sengers, F.; Schraven, D.; Caprotti, F.; Dayot, Y. The Smart City as Global Discourse: Storylines and Critical Junctures across 27 Cities. J. Urban Technol. 2019, 26, 3-34. [CrossRef]

49. Queensland Government. Queensland Globe. Available online: https:/ / bit.ly/2KqWUTg (accessed on 7 September 2021).

50. Creative Commons. Attribution 3.0 Australia (CC BY 3.0 AU). Available online: https:/ / bit.ly/2OmJIVj (accessed on 7 September 2021).

51. Howes, M.; Dedekorkut-Howes, A. The Adaptation Roller-Coaster: Planning for Climate Change on the Gold Coast, Queensland. In Proceedings of the State of Australian Cities Conference Adelaide: 8th State of Australian Cities National Conference, Adelaide, Australia, 28-30 November 2017; pp. 1-12. Available online: https:/ / bit.ly/3C5rnzW (accessed on 17 June 2021).

52. CoGC. Gold Coast Transport Strategy 2031-Mid-Life Review Summary; CoGC, 2019. Available online: https://bit.ly/3kstlnl (accessed on 17 June 2021).

53. Farndon, D.; Burton, P. Avoiding the White Elephants: A New Approach to Infrastructure Planning at the 2018 Gold Coast Commonwealth Games? Qld. Rev. 2019, 26, 128-146. [CrossRef]

54. Hulse, K.; Reynolds, M.; Nygaard, C.; Parkinson, S.; Yates, J. The Supply of Affordable Private Rental Housing in Australian Cities: ShortTerm and Longer-Term Changes; Australian Housing and Urban Research Institute, 2019. Available online: https://bit.ly/3o3LABs (accessed on 20 June 2021).

55. CoGC. Corporate Plan-Gold Coast 2022; CoGC, 2018. Available online: https:/ / bit.ly/3fbHaDC (accessed on 17 June 2021).

56. Alizadeh, T.; Irajifar, L. Gold Coast Smart City Strategy: Informed by Local Planning Priorities and International Smart City Best Practices. Int. J. Knowl.-Based Dev. 2018, 9, 153-173. [CrossRef]

57. Australian Government. Smart Cities Plan; Australian Government, 2016. Available online: https://bit.ly/3nSiJ3b (accessed on 2 August 2021).

58. Nothling, L. Brisbane's 2032 Olympic Games Venues Will Be a Mix of New and Old. Here's How It Will Look. ABC News. Available online: https:/ /ab.co/3lcqX4X (accessed on 24 July 2021).

59. Australian Government. South East Queensland City Deal—Statement of Intent; Queensland Government, 2019. Available online: https: / / bit.ly/3lP0g4J (accessed on 2 August 2021).

60. Ersoy, A. Smart Cities as a Mechanism towards a Broader Understanding of Infrastructure Interdependencies. Reg. Stud. Reg. Sci. 2017, 4, 26-31. [CrossRef]

61. Yigitcanlar, T.; Kankanamge, N.; Vella, K. How Are Smart City Concepts and Technologies Perceived and Utilized? A Systematic Geo-Twitter Analysis of Smart Cities in Australia. J. Urban Technol. 2020, 28, 135-154. [CrossRef]

62. Brisbane City Council. Our Smart, Prosperous City. Available online: https:/ /bit.ly /2YI8jIT (accessed on 7 September 2021).

63. Brisbane City Council. Smart, Connected Brisbane Framework; Brisbane City Council, 2017. Available online: https://bit.ly/3E0 BWFr (accessed on 7 September 2021).

64. Dowling, R.; McGuirk, P.; Sophia, M. Realising Smart Cities: Partnerships and Economic Development in the Emergenece and Practices of Smart in Newcastle, Australia. In Inside Smart Cities: Place, Politics and Urban Innovation; Karvonen, A., Cugurullo, F., Caprotti, F., Eds.; Routledge: London, UK, 2018; ISBN 978-1-3511-6620-1.

65. CoGC. Our Sustainable City. Available online: https:/ / bit.ly/3E3weCN (accessed on 8 September 2021).

66. Coucil of Mayors. Transforming SEQ: The SEQ City Deal Proposition; Council of Mayors, 2019. Available online: https://bit.ly/38 WUTL4 (accessed on 7 September 2021).

67. Committee for Brisbane. Advocacy. 2021. Available online: https://bit.ly/3zZUFi5 (accessed on 7 September 2021).

68. Giffinger, R.; Fertner, C.; Kramar, H.; Kalasek, R.; Pichler-Milanovic, N.; Meijers, E. Smart Cities Ranking of European Medium-sized Cities; University of Copenhagen, 2007. Available online: https: / bit.ly/31Q7422 (accessed on 20 July 2021).

69. Batty, M.; Axhausen, K.W.; Giannotti, F.; Pozdnoukhov, A.; Bazzani, A.; Wachowicz, M.; Ouzounis, G.; Portugali, Y. Smart Cities of the Future. Eur. Phys. J. Spec. Top. 2012, 214, 481-518. [CrossRef]

70. Cohen, B. Methodology for 2014 Smart Cities Benchmarking. Available online: https://bit.ly/3faZVa6 (accessed on 20 March 2021).

71. Bajracharya, B.; Cattell, D.; Khanjanasthiti, I. Challenges and Opportunities to Develop a Smart City: A Case Study of Gold Coast, Australia. In Proceedings of the REAL CORP 2014: Plan It Smart, Clever Solutions for Smart Cities, Vienna, Austria, 21-23 May 2014; pp. 119-129. 
72. Tonmoy, F.N.; Hasan, S.; Tomlinson, R. Increasing Coastal Disaster Resilience Using Smart City Frameworks: Current State, Challenges, and Opportunities. Front. Water 2020, 2, 1-13. [CrossRef]

73. CoGC. Get Set for Our Cultural Evolution. Available online: https:/ /bit.ly/37bTSO6 (accessed on 7 March 2021).

74. Breen, S. The Gold Coast: The Sun-Drenched Sin City that Wants to Shine. Available online: https://bit.ly/3j7oq9c (accessed on 12 January 2021).

75. Armitage, L.; Khanjanasthiti, I.; Chand, S. Micro Houses: Trends and Implications on the Gold Coast. In Proceedings of the 4th Australian Regional Development Conference: Regional Development in a Changing World, Coffs Harbour, Australia, 11-12 September 2017.

76. Cansdale, D. Gold Coast Rental Market Described as “Hectic" as Vacancy Rates Drop. Available online: https://ab.co/3zPMvbx (accessed on 7 March 2021).

77. Alizadeh, T.; Irajifar, L. Towards Gold Coast Smart city: A Combination of Local Planning Priorities and International Best Practices. In Proceedings of the 8th State of Australian Cities National Conference, Adelaide, Australia, 28-30 November 2017. Available online: https:/ / bit.ly/3BURB7q (accessed on 7 March 2021).

78. Bailey, M. Commonwealth Games Rapid Response Transport Centre Ready to Go. Available online: https://bit.ly/3txj6B8 (accessed on 10 September 2021).

79. Queensland Government. Springbrook Wireless Sensor Network—Information Sheet. Available online: https://bit.ly/3xeJzUe (accessed on 7 March 2021).

80. GCWA. Our Organisation. Available online: https:/ /bit.ly/3xddyvL (accessed on 8 September 2021).

81. CoGC. Drinking Water Quality Results. Available online: https:/ /bit.ly/2YJK4Ko (accessed on 8 September 2021).

82. CoGC. Smart Water Meter Solutions Project. Available online: https://bit.ly/3tugBiH (accessed on 9 September 2021).

83. Bailey, M. Smart Ticketing Touches on for the First Time on Gold Coast. Available online: https://bit.ly/3ldD81s (accessed on 22 January 2021).

84. Palaszczuk, A.; Trad, J. Stage Two of Gold Coast Light Rail in Track for Commonwealth Games. Available online: https: / / bit.ly/3ySW5cV (accessed on 30 March 2021).

85. CoGC. Our Energy Responsibilities. Available online: https://bit.ly/3ldzbIc (accessed on 10 September 2021).

86. NBN Co. NBN Rollout Map. Available online: https:/ / bit.ly/2WBPHt3 (accessed on 23 July 2021).

87. Alizadeh, T. The Spatial Justice Implications of Telecommunication Infrastructure: The Socio-Economic Status of Early National Broadband Network Rollout in Australia. Int. J. Crit. Infrastruct. 2015, 11, 278-296. [CrossRef]

88. Acharya, M. Australia's Internet Speed Ranks below India, Kazakhstan or Latvia. Available online: https://bit.ly/3zPuzOb (accessed on 15 March 2021).

89. Hobday, L.; Sas, N. Coronavirus Affecting Internet Speeds, as COVID-19 Puts Pressure on the Network. Available online: https://ab.co/3ydjdDq (accessed on 12 January 2021).

90. Australian Institute of Family Studies. Employment E Work-Family Balance in 2020; Australian Institute of Family Studies, 2021. Available online: https:/ / bit.ly/37GbJwY (accessed on 7 September 2021).

91. City of Adelaide. Ten Gigabit Adelaide. Available online: https:// bit.ly/3gn900n (accessed on 13 August 2021).

92. Preiss, B. The Need for Speed: Bendigo Is out to Deliver the Fastest Internet in Australia. Available online: https://bit.ly/3g2hEB0 (accessed on 12 August 2021).

93. Sunshine Coast Regional Council. Digital Connectivity. Available online: https:/ /bit.ly/3yOHW16 (accessed on 12 August 2021).

94. CoGC. Digital Connectivity. Available online: https:// bit.ly/3BGmSei (accessed on 7 September 2021).

95. CoGC. Data Intelligence. Available online: https:/ / bit.ly/3BHsBR6 (accessed on 7 September 2021).

96. CoGC. City Budget 20-21 Paves Roads to Recovery. Available online: https:/ /bit.ly/31QYsZj (accessed on 23 July 2021).

97. CoGC. Film Gold Coast; CoGC, 2019. Available online: https:/ / bit.ly/3fcW8Jj (accessed on 13 August 2021).

98. Queensland Airports Limited. Productivity Commission, Economic Regulation of Airports; Productivity Commission, 2018. Available online: https:/ / bit.ly/2LVRPTC (accessed on 7 September 2021).

99. Khanjanasthiti, I. Planning for Economic Development around a Second-Tier Airport: A Case Study of Gold Coast Airport. Ph.D. Dissertation, Bond University, Gold Coast, Australia, 2021. Available online: https://bit.ly/3BX3IAV (accessed on 7 September 2021).

100. O'Hare, D.; Bajracharya, B.; Khanjanasthiti, I. Transforming the Tourist City into a Knowledge and Healthy City: Reinventing Australia's Gold Coast. In Proceedings of the 7th International Forum on Knowledge Asset Dynamics, 5th Knowledge Cities World Summit: Knowledge, Innovation and Sustainability: Integrating Micro \& Macro Perspectives (IFKAD-KCWS 2012), Matera, Italy, 13-15 June 2012; pp. 2488-2517.

101. The Gold Coast Innovation Hub. About Us. Available online: https: / bit.ly/37bwZdC (accessed on 20 July 2021).

102. CoGC. The Mayor's Telstra Technology Award Finalists Announced. Available online: https://bit.ly/3xeeXCn (accessed on 15 July 2021).

103. CoGC. Sister City Relationships \& International Partnerships. Available online: https://bit.ly/2XzvlRB (accessed on 11 March 2021).

104. Sunshine Coast Regional Council. Smart City Framework. Available online: https://bit.ly/3zzmNHL (accessed on 13 August 2021). 
105. Logan City Council. City Futures Strategy; Logan City, 2018. Available online: https://bit.ly/3zUd4fx (accessed on 13 August 2021).

106. OASC Secretariat. Australian Cities Join Open \& Agile Smart Cities. Open \& Agile Smart Cities. Available online: https: / / bit.ly /3zSE7YU (accessed on 14 March 2021).

107. Leading Inside Out; Collective Impact Forum; FSG. Community Engagement Toolkit; Collective Impact Forum, 2017. Available online: https:/ / bit.ly/3zPveix (accessed on 13 August 2021) 